\title{
Antigen-G of Larva Serum of Musca domestica as an Immunoglobulin Production Promoter in Goats under an Organic Maintenance
}

\author{
Laurentius Rumokoy ${ }^{1.2}$, Hengky Kiroh, Ivonne Maria Untu², Geertruida Assa², Santie Turangan² and Wisje Lusia \\ Toar $^{2 *}$
}

\author{
${ }^{1}$ Entomology Program, Postgraduate School of Sam Ratulangi University, Manado, Indonesia \\ 2Departemen of Animal Sciences, Faculty of Animal Husbandry, Sam Ratulangi University, Manado, Indonesia \\ *Corresponding Author: wisje_toar@live.com
}

\begin{abstract}
This experiment aimed to reveal the effect of serum $\mathrm{G}$-antigen of $M$. domestica insect larvae (LAS) as promoter antigen on serum immunoglobulin production in organically managed goat livestock. This study used 12 local goats which were divided into two groups: as a control group and treated group receiving treatment. Insect rearing was conducted to obtain the larvae, the antigen- $G$ was then extracted from the larvae to be used as promoter antigen to enhance the serum antibody production which was subcutaneously immunized in experimental goats and incubated for a period of 14 days. Blood collection of $2.5 \mathrm{ml}$ was taken through the jugular vein and then carried out a quantification of serum protein level indicating the antibody proportion of goats. The data of the LSA extract proportion level were statistically analyzed with t-test, and the quality classification level of serum immunoglobulin of animal groups were statistically analysed. The results showed that the serum of animals treated with LSA of $M$. domestica resulted in a higher level of immunoglobulin $(P<0.01)$ compared to the control. We conclude that the treatment of larva antigen serum (LAS) of $M$. domestica increases the proportion of immunoglobulin serum of goats.
\end{abstract}

Keywords: insect, Musca domestica, antigen, antibody, goats

\begin{abstract}
Abstrak. Percobaan ini bertujuan untuk mengungkapkan efek dari serum G-antigen larva M. Domestica (LAS) sebagai promotor produksi imunoglobulin ternak kambing yang dikelola secara organik. Studi ini menggunakan 12 kambing lokal yang dibagi menjadi dua kelompok: sebagai kelompok kontrol dan kelompok perlakuan yang menerima LAS. Rearing serangga dilakukan untuk mendapatkan larva sebagai sumber antigen-G. Antigen-G diekstraksi dari larva sebagai antigen promotor dalam meningkatkan produksi imunoglobulin serum pada kambing eksperimen. Setelah diimunisasi dan diinkubasi pada kambing percobaan selama 14 hari, sampel darah sebanyak 2,5 ml diambil menggunakan jarum suntik yang melalui vena jugular. Sesudah itu dilakukan kuantifikasi protein Ig yang mengindikasi level antibodi. Data tingkat proporsi ekstrak LAS dianalisis secara statistik dengan T-Test untuk mendapatkan proporsi tingkat kualitas serum immunoglobulin dari kelompok hewan yang menerima perlakuan dan dibandingkan kelompok kontrol. Hasil penelitian menunjukkan bahwa serum hewan yang menerima perlakuan LAS $M$. domestica menghasilkan tingkat proporsi antibodi yang lebih tinggi secara sangat signifikan $(P<0,01)$ dibandingkan dengan kontrol. Kami menyimpulkan bahwa zat antigen-G (LSA) dapat mendukung upaya untuk meningkatkan produksi ternak kambing organik dengan meningkatkan tingkat antibodi total yang bersirkulasi dalam darah.
\end{abstract}

Kata kunci: serangga, Musca domestica, antigen, antibodi, kambing

\section{Introduction}

The role of insect as an antigen source for livestock immunity system toward from threat of various types of germs (Rumokoy et al. 2017) has begun attracting scientists to study its potential to be an alternative solution for immune response effect (Cherniack, 2010; Breijo et al. 2016; Rumokoy et al. 2018). These substances could be applied to goats (Toar et al. 2017). The development of local goat farms in Indonesia which handled under traditional manner are closely related to the development of organic livestock without using any drugs or industrial or synthetic chemicals in this kind of livestock activities. Organic livestock products still need to be improved because it has become an option for consumers. Organic farming has begun to experience a development in various countries, including in Indonesia. The number of livestock is small with relatively higher production costs compared to regular animal husbandry. The time needed to produce is generally longer than with a normal farm. This condition causes the price of 
organic food products to be relatively more expensive than the price of non-organic food products. Brown and Sperow, (2005) reported the cost of consuming organic diet. The interest to purchase organic food could be related to the life-style and perception of the consumer (Denver and Christensen, 2015) and it is considered to be safe and healthy for consumers (Ueasangkomsate and Santiteerakul, 2016; Huber et al., 2011).

The consumers are aware of the importance of organic foods which are safe for health and eco-friendly. This point of view is in line with the scientific review as reported by Huber et al. (2011). In contrast, the major obstacle faced by this traditional type of livestock is the threat of parasite and microbial pathogenic infection (Rumokoy and Toar, 2014). This condition is a challenge in cultivating local goat farms and leads many farmers to become less passionate to continue their livestock anymore for the reason of inefficient and insufficient benefits. Such farms have to be supported to meet food market distribution sufficiently in the rather for local and national market scale.

\section{Materials and Methods}

The experiment was conducted at Center of Agricultural Training (SAL) Lotta Pineleng, Minahasa, North Sulawesi Indonesia. Twelve young goats were used in this experiment and were divided in two groups: A1 was a control group received $0 \mu \mathrm{l}$ of LAS and A2 was the treatment group treated with $10 \mu \mathrm{L}$ LAS of $M$. domestica as antigen promoter to enhance serum antibody production. To assure the water consumption of goats, a water reservoir was placed in their pen. The antigens-G were extracted from insect larva of M. domestica 6 to 8 day old. The insect rearing was realized by adapting to previous methods (Keiding and Arevad, 1964). The antigens were injected subcutaneously to the animals and after 14 days of incubation blood samples were collected in a vacuum tube added with EDTA as anticoagulant.
Blood samples collection $(2.5 \mathrm{ml})$ were taken through a jugular vein, after that samples were centrifuged to obtained blood serum, and then a semi-quantitative analysis was done by using a hand refractometer to detect the \%brix value as proportion of serum protein level of goats indicating the level total of antibody serum (TAS).

The data of the LSA extract response on protein immunoglobulin proportion level were statistically analyzed with t-test, and the quality classification level of serum immunoglobulin quality of animal groups were statistically analyzed according to Mann-Whitney (Zar, 1996). Whereas local goat population data was oriented to goat farms in the regions of North Sulawesi Province by using secondary data, among others, originating from Central Statistics Agency (BPS-Sulut, 2020) as well as other supporting data from related scientific references.

\section{Results and Discussion}

During the observation, all of the animals in the experiment site have been showing a good health condition. The immune responses in goats using insect antigen on immunoglobulin level after four-teen days of immunization with larva antigen serum (LAS) are illustrated in figure 1 and figure 2 . The LAS effect on immunoglobulin level was discovered by a \%brix value of goats. It was observed that an average proportion of immunoglobulin level of group A1 animals as control group was $8.53 \%$ Brix. This value was lower than in animals of the treatment group which was $9.42 \%$ Brix. The statistical analysis result obtained showed that the \%Brix value between group $A 1$ and group $A 2$ was very significantly different $(P<0.01)$.

The figure 1 above illustrated that a treatment with $10 \mu$ l of LAS to animals in group A2 was able to increase the \%Brix value compared to the value in the control group (A1). These results are in line with scientific research conducted using thoraxial serum extracted from 
the thoracic insect of Apis mellifera as reported by Toar et al. (2018). This study confirms that antigens of LAS are useful for increasing the production of goat livestock antibodies. On the other side Chen et al. (2015) used peptide fraction from the larva of Musca domestica as an immunomodulatory. Similarly, Ai et al (2013) recorded a high immune-response in mice after using a protein-enriched fraction isolated from larvae of $M$. domestica.

A quality level of immunoglobulin serum level in this study represented in Figure 2. The category $A$ in the figure 2 indicated that the immunoglobulin ( $\mathrm{Ig}$ ) levels achieved more than $10 \mathrm{gr} / \mathrm{L}$ ( $>8.5 \%$ Brix) while as category B signified an Ig concentration under 10gr/L (<8.5\%Brix).

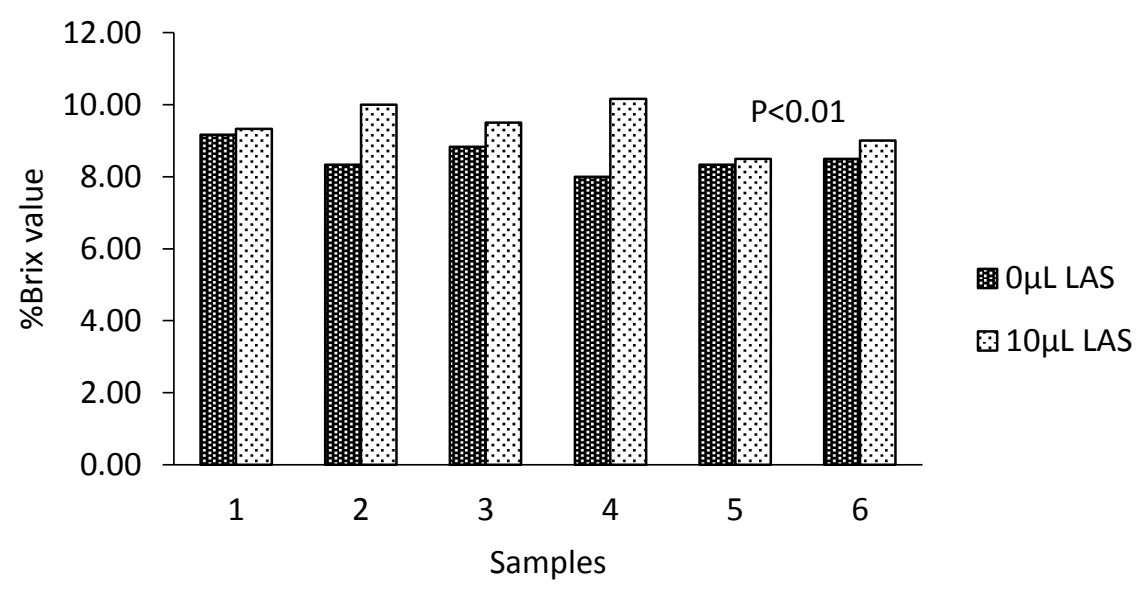

Figure 1. Effect of LAS on Serum \%Brix Value

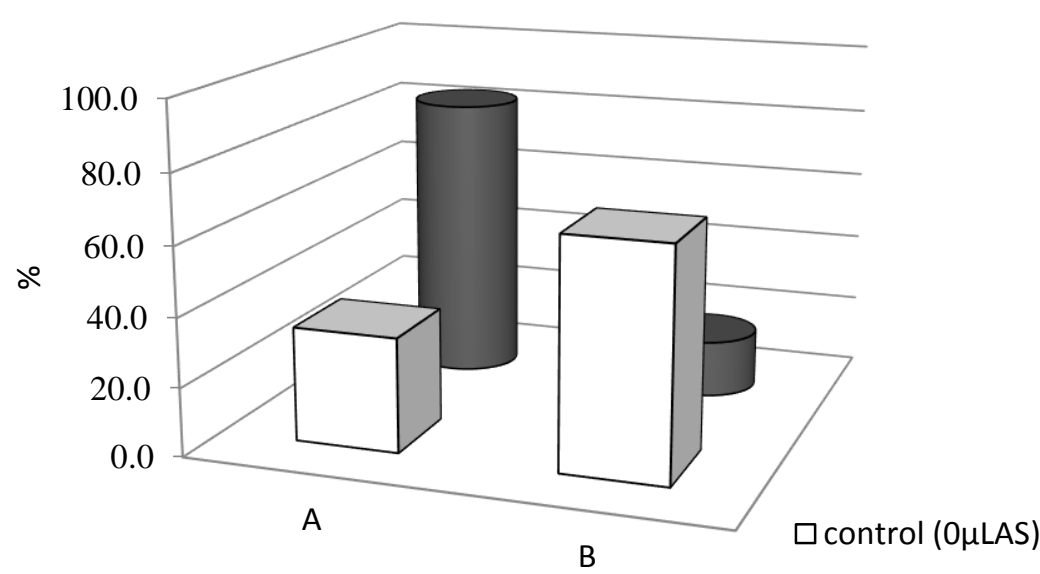

Category of Ig Serum Proportion Level

Figure 2. Quality Level of Immunoglobulin Serum of Experiment Animals

The result showed that only $33 \%$ of animals in control group reached in category A level while in $67 \%$ of the animals in this group were included as category B. In contrast to the animals in treatment group (treated with $10 \mu$ of LAS):
83.3\% had a good concentration of Ig in their blood serum, but only $16.7 \%$ had an Ig level under $10 \mathrm{gr} / \mathrm{L}$. The attention to animal immunity system of an organic livestock by using insect antigens is important to do for improving the 
animal production (Rumokoy and Toar, 2014). These results correlate with a study of Ariantini et al. (2019) which showed that an immunization with $M$. domestica larvae antigens slightly increased sheep antibodies. These achievements show that flies are potentially to support animal husbandry improvement (Toar et al. 2019; Ameri et al. 2008). These results become new discoveries of the current research conducted so far using insect antigens that despite the negative side of these insects as vectors of pathogenic agents, it had a positive side as an immuno-enhancer Rumokoy et al. (2017). Utilization of salivary fly protein has been studied in overcoming several pathological problems in experimental mammal individuals. The progress of such studies is in line with the report of Breijo et al. (2018) indicated that proteins obtained from the substances of horn fly saliva (Haematobia irritans) were able to inhibit the inflammatory in an experiment using mice. The protein which is contained in the body of the Haematobia irritans insect functions as a molecule capable in controlling the insect infestation in livestock as traced by Breijo et al. (2017). On the other hand, insects have the potential to fly as transmitters of pathogenic agents (Baldacchino et al. 2013). The general use of insects in organic farming receives positive response from the farmers (Chia et al. (2019), and it becomes an option of using insects in the business under a green technology (Hinson et al. 2019).

Utilization of insects for organic livestock production is very suitable to be applied to farms that use local natural ingredients for their animals. Smallholder farms carried out in various regions in North Sulawesi Province are almost entirely dominated by farms that are managed organically, especially on local goat farms which rely on local natural resources around the farms.

The population of local goats in this area recorded in 2018 was 111,603 heads. Goat population in North Sulawesi Province is almost entirely traditionally bred and spread in all regencies and cities in the province.

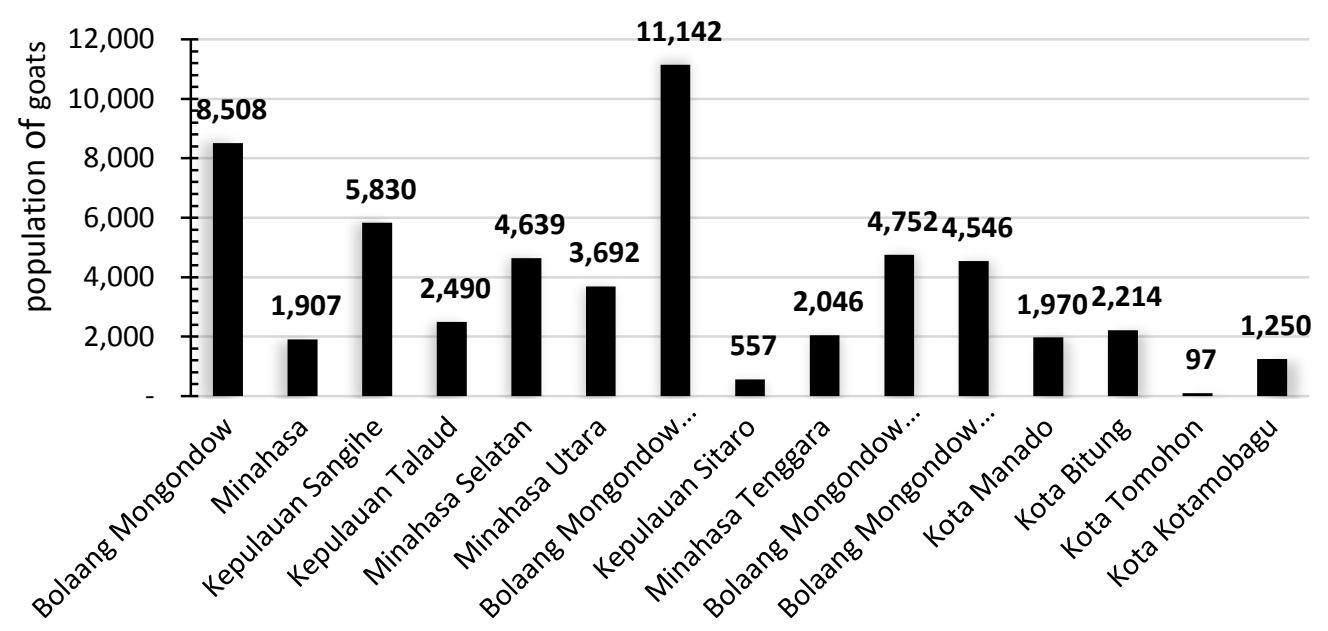

Sources: BPS (processed)

Figure 3. Population of goat in the regions of North Sulawesi Indonesia in the year of 2018

The immunity response shown in this study could direct antigen-G larvae to become a friendly vaccine candidate for organic livestock improvement, especially for the health management. This achievement is expected to synergize with the local goat breeding business in the smallholder areas such as those scattered in North Sulawesi Province including in other areas that apply green technology.

The attention for efforts to increase organic food products originating from goats will have an impact on improvement of goats' production 
that are carried out by smallholders both in terms of quantity and quality. This improvement of organic farming correlates with an increase of consumers' socio-economic level who buy organic food products so that the prospect of the organic products market will be more promising, and in turn it will have an impact on improving the socio-economics of the stakeholders themselves.

\section{Conclusion}

The treatment of larva antigen serum (LAS) of $M$. domestica increases the proportion of immunoglobulin serum of goats. The results of this initial research need to be continued in relation with the antibody characterization such as the structure and molecular weight of immunoglobulins in a response to larval antigen$G$ applied to livestock and at the same time to explore the role of protein fraction as natural substance obtained from $M$. domestica larvae on the mechanism of livestock immunity.

\section{Referencess}

Ai H, Wang F, Zhang N, Zhang L, Lei C. 2013. Antiviral, immunomodulatory, and free radical scavenging activities of a protein-enriched fraction from the larvae of the housefly, Musca domestica. J Insect Sci 13:112

Ameri M, X Wang, MJ Wilkerson, MR Kanost, and AB Broce. 2008. An Immunoglobulin Binding Protein (Antigen 5) of the Stable Fly (Diptera: Muscidae) Salivary Gland Stimulates Bovine Immune Responses. J Med Entomol. 45(1): 94-101. doi: 10.1603/0022-2585(2008)45[94:aibpao]2.0.co.

Ariantini B, H Ratnani, EM Luqman and P Hastutiek. 2019. Antibody Titers in The Sheep which were Immunized Antigen of Whole Protein from Third Instar Larvae Musca domestica. IOP Conference Series: Earth and Environmental Science, Volume 217, Number $1 . \quad$ doi:10.1088/17551315/217/1/012022

Baldacchino F, V Muenworn, M Desquesnes, F Desoli, T Charoenviriyaphap, G Duvallet. 2013. Transmission of pathogens by Stomoxys flies (Diptera, Muscidae): a review. Parasite. doi: 10.1051/parasite/2013026. 20, 26.

BPS-Sulut, 2020. Populasi Ternak Menurut Kabupaten/Kota di Sulawesi Utara Tahun 2008 2018. Badan Pusat Statistik Provinsi Sulawesi
Utara. Statistik Sektorial, up-dated 24 January 2020.

https://sulut.bps.go.id/subject/24/peternakan.ht ml\#subjekViewTab4.

Breijo M, E Esteves, B Bizzarro, PG Lara, JB Assis, S Rocha, L Pastro, C Fernández, A Meikle, A SáNunes. 2018. Hematobin is a novel immunomodulatory protein from the saliva of the horn fly Haematobia irritans that inhibits the inflammatory response in murine macrophages. Parasit Vectors. 11(1):435. doi: 10.1186/s13071018-3017-z.

Breijo M, S Rocha, X Ures, L Pastro, P Alonzo, C Fernández, A Meikle. 2017. Evaluation of Hematobin as a Vaccine Candidate to Control Haematobia irritans (Diptera: Muscidae) Loads in Cattle. J Econ Entomol. 110(3):1390-1393. doi: 10.1093/jee/tox104.

Breijo M, L Pastro, S Rocha, X Ures, P Alonzo, M Santos, C Bolatto, C Fernández, A Meikle. 2016. A Natural Cattle Immune Response Against Horn Fly (Diptera: Muscidae) Salivary Antigens May Regulate Parasite Blood Intake. J Econ Entomol. 109(4): 1951-1956. doi:10.1093/jee/tow133.

Brown C, M Sperow. 2005. Examining the Cost of an All-Organic Diet. Examining the Cost of an AllOrganic Diet. 36(1).

Chen L, Zhang J, and H Sun. 2015. Immunological adjuvant effect of the peptide fraction from the larvae of Musca domestica. BMC Complementary and Alternative Medicine 15:427

Cherniack EP. 2010. Bugs as Drugs, Part 1: Insects. The "New" Alternative Medicine for the 21st Century? Alternative Medicine Review 15(2):124-135.

Chia SY, CM Tanga, J van Loon, M Dicke. 2019. Insects for sustainable animal feed: inclusive business models involving smallholder farmers. Current Opinion in Environmental Sustainability. 41: 2330. https://doi.org/10.1016/i.cosust.2019.09.003

Denver S, and T Christensen. 2015. Organic food and health concerns: a dietary approach using observed data. NJAS - Wageningen Journal of Life Sciences. 74-75: 9-15. https://doi.org/10.1016/j.njas.2015.05.001.

Hinson R, R Lensink, A Mueller. Transforming agribusiness in developing countries: SDGs and the role of FinTech. Current Opinion in Environmental Sustainability. 41:1-9. https://doi.org/10.1016/i.cosust.2019.07.002.

Hubera M, E Rembiałkowska, D Średnicka, S.Bügel, LPL van de Vijver. 2011. Organic food and impact on human health: Assessing the status quo and prospects of research. NJAS - Wageningen Journal of Life Sciences 58:103-109. https://doi.org/10.1016/j.njas.2011.01.004. 
Keiding J and K Arevad. 1964. Procedure and equipment for rearing a large number of house fly strains. Bull.Org.mond.Santé. 31:527-528.

Rumokoy L, Posangi J, Toar WL, and J Lopez-Aban. 2018. An expectation of bio-resource function against parasite infection on animal health. Sci. Papers. Series D. Animal Science 61(1):216-219. http://animalsciencejournal.usamv.ro/pdf/2018/i ssue 1/Art38.pdf.

Rumokoy L, S Adiani, GJV Assa, WL Toar, JL Aban. 2017. Entomology contribution in animal immunity: Determination of the crude thoraxial glandular protein extract of Stomoxys calcitrans as an antibody production enhancer in young horses. 49 (3):140-143.

DOI https://doi.org/10.4081/jear.2017.7074

Rumokoy L and WL Toar. 2014. The Equine colostrums of milk treatment against pathogenic agent. Scientific Papers. Series D. Animal Science 57:174-177.

Toar WL, C Kaunang, IM Untu, L Rumokoy, H Kiroh. 2017. The empowerment of crude extract antigens-G of insect on goat immunity enhancement: An entomology contribution in animal husbandry. Scientific Papers: Series $D$, Animal Science 60:271-273.
Toar WL, M Tulung, V Memah, E Pudjihastuti, Rumokoy L, Posangi J, and IM Untu. 2018 The Presence of insects in animal farm in North Sulawesi. Scientific Papers. Series D. Animal Science 61(1):220-224.

Toar WL, L Rumokoy, IM Untu, G Assa. 2018. Insect Crude Thoraxial Antigen-G Extracted from Apis mellifera to Enhance Serum Immunoglobulin of Goats: An Entomology Contribution. Animal Science. Animal Production. 20(2):133-138. http://dx.doi.org/10.20884/1.jap.2018.20.2.608.

Toar WL, LJM Rumokoy, E Pudjihastuti, H Manangkot, B Bagau and IM Untu. 2019. Effect of Supplementation of Combination of Curcuma and BSF Maggot Meal in Rations on Accumulative Weight of Native Chickens. IOP Conference Series: Earth and Environmental Science, Volume 372, conference $\quad 1 . \quad$ doi:10.1088/1755$1315 / 372 / 1 / 012009$.

Ueasangkomsate P, S Santiteerakul. 2016. A study of consumers' attitudes and intention to buy organic foods for sustainability. Improving Sustainability Concept in Developing Countries. Procedia Environmental Sciences 34(2016):423-430. doi: 10.1016/j.proenv.2016.04.037.

Zar JH. 1996. Biostatistical Analysis. Page 662. $3^{\text {rd }}$ Edition, Prentice Hall, Inc. 